\title{
30. DISTRIBUTION OF ORGANIC MATTER IN SEDIMENTS ALONG THE CALIFORNIA CONTINENTAL MARGIN ${ }^{1}$
}

\author{
Deborah Gilbert and Colin P. Summerhayes, Exxon Production Research Company, Houston, Texas
}

\section{INTRODUCTION}

As part of our continuing organic geochemical studies of sediments recovered by the Deep Sea Drilling Project, we have analyzed the types, amounts, and thermal alteration indices of organic matter in samples collected from the California continental margin on Leg 63 (Table 1). Some of the samples were frozen core; others were canned on site. Canned samples were analyzed for gas content (Table 2) using methods described by McIver (1972).

Our main objective was to see if the changes in surface circulation that had occurred through time off the California coast were reflected in changes in the type and amount of organic matter accumulating on the sea floor.

The samples fall into two groups: (1) the California Borderland group includes Site 467 in the San Miguel Gap (water depth $=2145 \mathrm{~m}$ ) and Site 468 on the Patton Escarpment (water depth $=1752 \mathrm{~m}$ ); (2) the other group, from the continental rise or deep sea, includes Site 469 at the foot of the Patton Escarpment (water depth $=3790 \mathrm{~m}$ ), Site 470 near Guadalupe Island (water depth $=3750 \mathrm{~m}$ ), Site 471 on the Baja continental slope (water depth $=3116 \mathrm{~m}$ ), and Site 473 at the mouth of the Gulf of California (water depth $=3267$ m) (Fig. 1). All samples are Cenozoic.

\section{METHODS}

After samples had been treated with warm, dilute $\mathrm{HCl}$ to remove carbonate minerals, the total organic carbon (here referred to as TOC) content of the samples was measured with a LECO carbon analyzer. Using a classification system described by Masran and Pocock (1979), we identified optically the different types of organic matter from slides prepared in the manner delineated by Staplin (1969).

\section{TYPE AND AMOUNT OF ORGANIC MATTER}

\section{California Borderland (Site 467, 468)}

At Site 468, the shallowest site, we analyzed one Pliocene(?) sample and four middle Miocene samples (Table 1). The younger sample is a nannofossil ooze that accumulated slowly at about $0.49 \mathrm{~cm} / 1000$ years; the older samples are diatomaceous silty clays that accumulated more rapidly at about $10 \mathrm{~cm} / 1000$ years. There is no change in organic facies (the assemblage of different types of organic matter) between the older and younger groups. Both are dominated by amorphous organic mat-

\footnotetext{
1 Initial Reports of the Deep Sea Drilling Project, Volume 63.
}

ter (probably marine-derived) with subordinate amounts of structured marine organic matter (Table 1).

At Site 467, Quaternary-upper Pliocene samples of diatomaceous silty clay have an average TOC content of $2.1 \%$. The underlying middle Pliocene and upper Miocene sediments are lithologically similar but with a somewhat higher TOC content (averaging 3.9\%). TOC content of the deepest upper Miocene sample reaches a maximum value of $7.8 \%$. Below it are middle Miocene siliceous and calcareous silty claystones with an average TOC content of $2.3 \%$. The organic-rich upper Miocene and younger facies are gassy and have velocities of 1.6 $\mathrm{km} / \mathrm{s}$; the middle Miocene facies contains less organic matter, is better cemented, less gassy, and has an average velocity of about $3.4 \mathrm{~km} / \mathrm{s}$. Rates of sedimentation change downcore from $7.5 \mathrm{~cm} / 1000$ years in the Quaternary, to 15 to $12.5 \mathrm{~cm} / 1000$ years in the Pliocene, to 5 $\mathrm{cm} / 1000$ years in the late Miocene and middle Miocene.

The three units defined by TOC content at Site 467 differ only slightly in organic facies. All are dominated by apparently marine-derived amorphous material. The youngest unit tends to have the most terrestrial material (pollen and spores, biodegraded and structured material), the middle unit has the most structured marine material, and the oldest unit has the least terrestrial material (Table 1).

Both of these shallow-water sites (Fig. 1) show a marked change in TOC from low values in the middle Miocene sediments to higher values in the younger sediments (Table 1).

Deep Continental Margin (Sites 469, 470, 471, 473)

Samples from relatively deep-water sites (i.e., water depth $>3000 \mathrm{~m}$ ) have TOC contents mostly less than $1 \%$ (averaging $0.9 \%$ for all samples analyzed). Amorphous organic matter is dominant. At Site 469, TOC content is lowest near the base of the section but slightly higher in the upper part of the section (Table 1). There is no enrichment in TOC in the upper Miocene, as at Site 467. From Site 470 we analyzed two samples, one upper Miocene, the other middle Miocene. Both are diatomaceous silty clays that accumulated at about $1.2 \mathrm{~cm} / 1000$ years and have low TOC contents (Table 1).

At Site 471, the TOC content is again moderately low (averaging $0.75 \%$ ). Although there is a marked change in lithology (from porcelanites to turbiditic silty clays) and an attendant increase in sedimentation rate (from $2-5 \mathrm{~cm} / 1000$ years in the upper Miocene-Quaternary to $20 \mathrm{~cm} / 1000$ years in the middle Miocene), neither TOC content nor organic facies seem affected (Table 1). 
Table 1. Total organic carbon percents (TOC) and kerogen concentrations and thermal alteration indices (TAI) for samples from the California continental margin.

\begin{tabular}{|c|c|c|c|c|c|c|c|c|c|c|c|c|c|}
\hline \multirow[b]{2}{*}{$\begin{array}{l}\text { Site } \\
\text { Hole } \\
\text { No. }\end{array}$} & \multirow[b]{2}{*}{$\begin{array}{l}\text { Core } \\
\text { No. }\end{array}$} & \multirow[b]{2}{*}{ Section } & \multirow[b]{2}{*}{$\begin{array}{l}\text { Interval } \\
(\mathrm{cm})\end{array}$} & \multirow[b]{2}{*}{$\begin{array}{l}\text { Depth below } \\
\text { Sea Floor } \\
\text { (m) }\end{array}$} & \multirow[b]{2}{*}{ Chronostratigraphy } & \multirow{2}{*}{$\begin{array}{l}\text { Total } \\
\text { Organic } \\
\text { Carbon } \\
\text { (wt. \%) }\end{array}$} & \multicolumn{6}{|c|}{ Kerogen Descriptions } & \multirow[b]{2}{*}{ TAl } \\
\hline & & & & & & & $\begin{array}{l}\text { Structured } \\
\text { Marine }\end{array}$ & Amorphous & $\begin{array}{l}\text { Pollen } \\
\text { and } \\
\text { Spores }\end{array}$ & $\begin{array}{c}\text { Biodegradable } \\
\text { Terrestrial }\end{array}$ & $\begin{array}{l}\text { Structural } \\
\text { Terrestrial }\end{array}$ & Coaly & \\
\hline 467 & 7 & 5 & Bottom & 61.0 & Quaternary & 1.91 & 10 & 30 & 20 & - & 30 & 10 & $1+$ \\
\hline 467 & 8 & 4 & Top & 67.5 & Quaternary-upper Pliocene & 1.80 & 10 & 70 & 5 & - & 10 & 5 & $1+$ \\
\hline 467 & 9 & 2 & Bottom & 75.5 & Quaternary-upper Pliocene & 2.68 & 10 & 80 & - & 5 & - & 5 & $1+$ \\
\hline 467 & 9 & 3 & Bottom & 77.0 & Quaternary-upper Pliocene & 4.02 & - & 95 & - & 5 & - & - & $1+$ \\
\hline 467 & 9 & 4 & Top & 77.0 & Quaternary-upper Pliocene & 4.62 & 10 & 90 & - & - & - & - & $1+$ \\
\hline 467 & 10 & 5 & Bottom & 89.0 & Pliocene & 3.47 & 10 & 75 & - & - & 5 & 10 & $1+$ \\
\hline 467 & 11 & 1 & Bottom & 93.0 & Pliocene & 3.26 & 5 & 80 & 5 & - & 5 & 5 & $1+$ \\
\hline 467 & 11 & 3 & Top & 94.5 & Pliocene & 3.03 & 20 & 55 & 5 & 5 & 5 & 10 & $1+$ \\
\hline 467 & 11 & 4 & Bottom & 97.5 & Pliocene & 4.36 & 10 & 60 & 5 & 10 & 5 & 10 & $2-$ \\
\hline 467 & 13 & 1 & Bottom & 112.0 & Pliocene & 3.75 & 10 & 60 & 5 & 15 & 5 & 5 & $2-$ \\
\hline 467 & 13 & 5 & Bottom & 118.0 & Pliocene & 3.98 & - & 80 & - & - & - & 20 & $2-$ \\
\hline 467 & 14 & 1 & Bottom & 121.5 & Pliocene & 3.61 & 10 & 70 & 5 & 5 & 5 & 5 & $1+$ \\
\hline 467 & 14 & 2 & Top & 121.5 & Pliocene & 3.70 & 20 & 80 & - & - & - & - & $1+$ \\
\hline 467 & 14 & 2 & Bottom & 123.0 & Pliocene & 3.57 & 20 & 80 & - & - & - & - & $1+$ \\
\hline 467 & 14 & 3 & Top & 123.0 & Pliocene & 3.55 & 5 & 85 & 5 & - & 5 & - & $1+$ \\
\hline 467 & 16 & 1 & Bottom & 140.5 & Pliocene & 3.68 & 5 & 75 & 5 & 5 & - & 10 & $1+$ \\
\hline 467 & 16 & 2 & Bottom & 142.0 & Pliocene & 3.61 & 10 & 65 & 5 & 10 & 5 & 5 & $2-$ \\
\hline 467 & 18 & 1 & Bottom & 159.5 & Pliocene & 3.22 & 10 & 65 & 5 & 10 & 5 & 5 & $2-$ \\
\hline 467 & 18 & 2 & Bottom & 161.0 & Pliocene & 4.03 & 20 & 75 & - & 5 & - & - & $2-$ \\
\hline 467 & 18 & 4 & Bottom & 164.0 & Pliocene & 4.68 & 10 & 70 & 5 & 10 & - & 5 & $2-$ \\
\hline 467 & 26 & 1 & Top & 234.0 & Pliocene & 1.91 & 10 & 80 & 5 & - & - & 5 & 2 \\
\hline 467 & 42 & 2 & Bottom & 392.0 & Pliocene & 4.13 & 10 & 90 & - & - & - & - & $2-$ \\
\hline 467 & 42 & 3 & Bottom & 393.5 & Pliocene & 3.93 & 10 & 90 & - & - & - & - & $2-$ \\
\hline 467 & 42 & 5 & Top & 398.0 & Pliocene & 4.03 & 10 & 90 & - & - & - & - & $2-$ \\
\hline 467 & 44 & 5 & Bottom & 412.4 & Pliocene & 4.67 & 5 & 90 & - & 5 & - & - & $2-$ \\
\hline 467 & 44 & 5 & Top & 411.0 & Pliocene & 3.08 & 5 & 90 & - & - & 5 & - & $2-$ \\
\hline 467 & 44 & 6 & Top & 412.5 & Pliocene & 3.21 & 5 & 90 & - & - & - & 5 & $2-$ \\
\hline 467 & 44 & 7 & Bottom & 414.0 & Pliocene & 3.52 & 10 & 90 & - & - & - & - & 2 \\
\hline 467 & 54 & 2 & $108-118$ & 502.6 & Upper Miocene & 4.36 & - & 99 & - & - & - & - & $1+$ \\
\hline 467 & 63 & 2 & $100-109$ & 588.0 & Upper Miocene & 7.84 & 10 & 85 & - & - & - & 5 & $1+$ \\
\hline 467 & 85 & 4 & $145-150$ & 801.5 & Middle Miocene & 1.69 & - & 90 & - & - & - & 10 & $1+$ \\
\hline 467 & 91 & 2 & $107-109$ & 854.1 & Middle Miocene & 1.98 & 5 & 90 & - & - & - & 5 & $1+$ \\
\hline 467 & 97 & 2 & $118-123$ & 911.1 & Middle Miocene & 2.42 & 30 & 70 & - & - & - & - & $1+$ \\
\hline 467 & 104 & 1 & $100-107$ & 976.0 & Middle Miocene & 2.50 & 20 & 70 & - & - & - & 10 & $1+$ \\
\hline 467 & 110 & 3 & $55-58$ & $1,035.0$ & Middle Miocene & 2.85 & 20 & 70 & - & - & 5 & 5 & $1+$ \\
\hline 468 & 2 & 3 & $120-129$ & 7.7 & Pliocene? & 2.68 & 20 & 70 & 5 & - & - & 5 & $1+$ \\
\hline 468 & 18 & 3 & $119-128$ & 160.1 & Middle Miocene & 1.74 & 20 & 70 & - & - & - & 10 & $1+$ \\
\hline 468B & 13 & 3 & $115-124$ & 163.2 & Middle Miocene & 0.26 & 20 & 80 & - & - & - & - & $1+$ \\
\hline 468B & 21 & 2 & $105-113$ & 256.6 & Middle Miocene & 1.61 & 10 & 90 & - & - & - & - & $1+$ \\
\hline $468 \mathrm{~B}$ & 37 & 1 & $115-120$ & 507.2 & Middle Miocene & 0.28 & 10 & 70 & - & 10 & - & 10 & $1+$ \\
\hline 469 & 2 & 2 & $100-109$ & 10.1 & Quaternary & 0.65 & - & 90 & - & - & - & 10 & $1+$ \\
\hline 469 & 12 & 5 & $112-120$ & 109.2 & Üpper Miocene & 0.64 & 5 & 70 & 5 & - & 10 & 10 & $1+$ \\
\hline 469 & 20 & 3 & $127-134$ & 182.8 & Middle Miocene & 0.45 & - & 85 & 5 & - & - & 10 & $1+$ \\
\hline 469 & 30 & 1 & $109-114$ & 274.1 & Upper middle Miocene & 0.94 & 10 & 85 & - & - & 5 & - & $1+$ \\
\hline 469 & 37 & 1 & $140-145$ & 341.4 & Middle Miocene & 0.37 & 5 & 90 & - & - & - & 5 & $1+$ \\
\hline 469 & 43 & 1 & $100-106$ & 388.1 & Upper Miocene & 0.35 & 10 & 55 & 10 & - & 5 & 20 & $1+$ \\
\hline 470 & 8 & 1 & $100-109$ & 69.6 & Upper Miocene & 0.24 & 15 & 40 & 5 & - & 15 & 25 & $2-$ \\
\hline 470 & 14 & 1 & $145-150$ & 124.6 & Middle Miocene & 0.35 & - & 85 & - & - & 5 & 10 & $1+$ \\
\hline 471 & 3 & 2 & $141-149$ & 21.6 & Quaternary & 0.80 & 10 & 60 & 5 & 10 & 5 & 10 & $1+$ \\
\hline 471 & 13 & 7 & $130-136$ & 123.1 & Upper Miocene & 0.84 & 25 & 75 & - & - & - & - & $1+$ \\
\hline 471 & 39 & 2 & $100-109$ & 363.6 & Middle Miocene & 0.93 & 10 & 75 & 10 & - & 5 & - & $1+$ \\
\hline 471 & 50 & 2 & $100-106$ & 468.1 & Middle Miocene & 0.61 & - & 90 & - & - & - & 10 & $1+$ \\
\hline 471 & 63 & 3 & $100-115$ & 593.1 & Middle Miocene & 0.64 & - & 85 & - & - & 10 & 5 & $1+$ \\
\hline 471 & 69 & 3 & $105-111$ & 650.1 & ? & 0.70 & - & 80 & - & - & 20 & - & $2-$ \\
\hline 473 & 2 & 2 & $125-131$ & 3.3 & Quaternary & 1.90 & 10 & 80 & - & - & - & 10 & $2-$ \\
\hline 473 & 7 & 1 & $100-109$ & 49.2 & Quaternary & 0.18 & 10 & 80 & - & - & - & 10 & $2-$ \\
\hline 473 & 23 & 2 & $123-130$ & 193.2 & Üpper Miocene & 0.91 & 10 & 75 & - & - & 10 & 5 & $2-$ \\
\hline
\end{tabular}

Note: - represents $0 \%$ of material present.

At Site 473 , the organic facies do not change downhole, but the TOC content is quite variable (Table 1). This variability is also documented by DSDP shipboard analyses. We believe that the changes reflect the influx of turbidites. There is a surprisingly high proportion of terrigenous material in this section. Core 2 (where we measured $1.9 \%$ TOC) contains abundant angular and subangular quartz and feldspar, plus glauconite, plant debris, and carbonized wood fragments-all signs of mass transport downslope, presumably from the Mexican mainland.

\section{THERMAL ALTERATION INDEX (TAI)}

Using the method of Staplin (1969), we measured thermal alteration indices from spore and pollen color. All of the samples that we analyzed are thermally immature (Table 1). They have not been heated to the point where they might yield hydrocarbons.

\section{GAS CONTENT}

Gas from Site 467 cans consists almost entirely of methane (Table 2). Of the wet gas fraction, ethane 
Table 2. Cuttings gas $\left(\mathrm{C}_{1}-\mathrm{C}_{4}\right)$ concentrations ( $\left.\mathrm{vol} / \mathrm{vol}\right)$ in air space of canned mud samples from Site 467: wet gas in $\mathrm{C}_{2}-\mathrm{C}_{4}$.

\begin{tabular}{cclrccc}
\hline Core & & & & Vol. HC Gas \\
No. & Section & Interval & $\begin{array}{c}\mathrm{CH}_{4} \text { in } \\
\mathrm{HC} \mathrm{Gas} \\
(\%)\end{array}$ & $\begin{array}{c}\mathrm{C}_{2}-\mathrm{C}_{6} \text { in } \\
\mathrm{HC} \text { Gas } \\
(\%)\end{array}$ & $\begin{array}{c}\mathrm{C}_{2} \mathrm{H}_{6} \text { in } \\
\text { Wet Gas } \\
(\%)\end{array}$ \\
\hline 7 & 5 & Bottom & 4,704 & 100 & 0 & 68 \\
8 & 4 & Top & 13,859 & 100 & 0 & 70 \\
9 & 2 & Bottom & 402 & 100 & 0 & 58 \\
9 & 3 & Bottom & 10,632 & 100 & 0 & 71 \\
9 & 4 & Top & 9,242 & 100 & 0 & 63 \\
10 & 5 & Bottom & 17,572 & 100 & 0 & 78 \\
11 & 1 & Bottom & 11,318 & 100 & 0 & 57 \\
11 & 3 & Top & 5,591 & 100 & 0 & 76 \\
11 & 4 & Bottom & 4,459 & 100 & 0 & 50 \\
13 & 1 & Bottom & 13,347 & 100 & 0 & 54 \\
13 & 5 & Bottom & 11,659 & 100 & 0 & 72 \\
14 & 1 & Bottom & 3,442 & 99 & 1 & 59 \\
14 & 2 & Top & 47,053 & 100 & 0 & 63 \\
14 & 2 & Bottom & 44,659 & 100 & 0 & 73 \\
14 & 3 & Top & 10,580 & 100 & 0 & 62 \\
16 & 1 & Bottom & 10,911 & 100 & 0 & 62 \\
16 & 2 & Bottom & 8,882 & 100 & 0 & 77 \\
18 & 1 & Bottom & 22,083 & 100 & 0 & 48 \\
18 & 2 & Bottom & 6,288 & 99 & 1 & 70 \\
18 & 4 & Bottom & 5,998 & 99 & 1 & 68 \\
26 & 1 & Top & 53,686 & 100 & 0 & 77 \\
42 & 2 & Bottom & 10,344 & 97 & 2 & 62 \\
42 & 3 & Bottom & 3,201 & 94 & 3 & 57 \\
42 & 5 & Top & 2,992 & 97 & 2 & 51 \\
42 & 5 & Bottom & 2,856 & 95 & 2 & 35 \\
44 & 6 & Top & 3,398 & 98 & 1 & 50 \\
44 & 6 & Top & 16,161 & 97 & 2 & 47 \\
44 & 7 & Bottom & 5,130 & 97 & 2 & 57 \\
\hline & & & & & & \\
\hline
\end{tabular}

$\left(\mathrm{C}_{2} \mathrm{H}_{6}\right)$ predominates. Preliminary shipboard data suggest that ethane increases in abundance downhole, resulting in a downward increase in the $C_{2} / C_{1}$ ratio. Our analyses confirm that ethane increases downhole relative to methane (Table 2); ethane averages $62 \%$ of the wet gas fraction $\left(\mathrm{C}_{2} \mathrm{H}_{6}\right.$ to $\left.\mathrm{C}_{4} \mathrm{H}_{10}\right)$.

Gas abundances are consistently high (averaging $12,873 \mathrm{ppm}$ ) and slightly above gas levels typical of Tertiary and Quaternary sediments cored by the DSDP (see reports by McIver 1973a, 1973b). There is twice as much gas in the samples from the California margin as there is in continental margin samples from the Japan Trench (i.e., $6418 \mathrm{ppm}-$ Gilbert et al., 1980). Some of the downhole variations in gas abundance listed in Table 2 may result from can leakage.

\section{DISCUSSION}

The southern California and Baja California continental margin differs considerably from the continental margin off Japan (Gilbert et al., 1980) in being so enriched in organic matter. Off Japan, which we consider to be typical of continental margins in areas where the water column is highly oxidizing, TOC values are low (average above $0.75 \%$ ) and organic facies are dominantly terrestrial (amorphous and structured marine algal material is only about $30 \%$ of the kerogen fraction). Presently in the California Borderland, marine sediments become enriched in organic matter where surface waters are highly productive (ensuring a good supply of marine organic matter) and where bottom waters contain small amounts of oxygen (ensuring that dead organic matter will be preserved). Upwelling promotes high biological productivity at the surface, and the de-

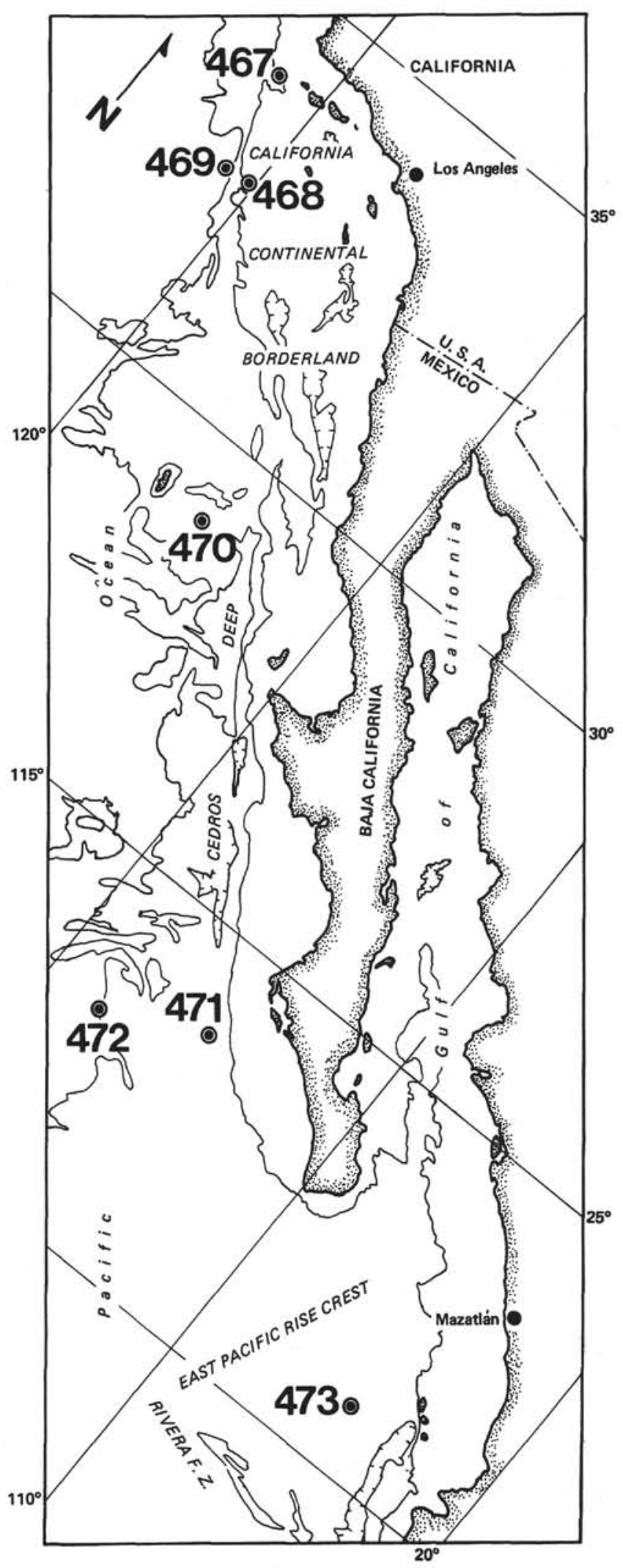

Figure 1. Location of Leg 63 sites. 
cay of sinking organic remains depletes oxygen levels in the underlying water column resulting in a distinct oxygen minimum zone (Emery, 1960). Where dissolved oxygen levels fall below about $0.5 \mathrm{ml} / 1$, benthic life is restricted. As a result, bottom sediments are often undisturbed, and large amounts of organic matter are preserved (Demaison and Moore, 1980). At slightly higher levels of oxygen (about 0.5 to $1.0 \mathrm{ml} / \mathrm{l}$ ), burrowing benthic organisms can survive, although there still may be substantial preservation of organic matter (Demaison and Moore, 1980). At higher levels of oxygen, bioturbation is extensive, and benthic organisms and oxidation processes remove most of the organic matter that reaches the bottom.

In the California Borderland there is presently a welldeveloped oxygen minimum zone in which oxygen levels drop to $0.5 \mathrm{ml} / 1$ or less, which encourages the preservation of organic matter (Emery, 1960). This zone extends at least as deep as $\mathbf{2 0 0 0}$ meters, at which depth the oxygen contents of bottom waters increase to 0.5 to $1.0 \mathrm{ml} / 1$ (Emery, 1960, fig. 97, p. 110). The Patton Escarpment site (468) falls within the present depth range of the minimum zone, the San Miguel Gap site (467) is just beneath it.

We suggest that the downhole changes in TOC content at Sites 467 and 468 reflect past fluctuations in the intensity of development of the oxygen minimum. Development of the minimum is linked to productivity; higher productivity at the surface leads to greater oxygen depletion at depth. Productivity, in turn, is linked to upwelling; sustained and vigorous upwelling promotes high productivity in surface waters. Changes in the pattern of upwelling reflect circulation changes that are also documented by a shift in regional isotherms (Ingle, 1973).

We interpret the vertical profiles of TOC content at Sites 467 and 468 in terms of an expansion of the oxygen minimum zone. This zone may not have intersected the sea floor at these sites in the middle Miocene. As a result, sediments of that age do not contain much organic carbon. In contrast, the zone probably intersected the sea floor in the late Miocene at Site 467 and in the Pliocene at both sites when more organic-rich sediments were deposited and preserved. It may intersect the sea floor presently at Site 468 (we have no modern samples, but this site is within the present oxygen minimum zone defined by Emery's fig. 97, 1960), but it does not do so at Site 467.

This interpretation does not account for vertical tectonic movements of the sea floor. The middle to late Miocene increase in TOC content at Site 467 could be explained, if the sea floor had risen into the oxygen minimum layer at this time. Similarly, the decrease in TOC values from the Pliocene into the Quaternary could reflect sinking of the sea floor below the oxygen minimum. We favor the oceanographic rather than the tectonic control, because paleontological data (Ingle, 1973) suggest significant temporal changes in the intensity of circulation in this region. Changes in rate of sedimentation appear to affect neither TOC content nor organic facies in the Borderland at Site 467.
The widespread occurrence of Miocene-Pliocene phosphorites may be an additional clue to unusual circulation conditions and nutrient supply in the California Borderland in the late Miocene-Pliocene (Emery, 1960). The association between phosphorites and organic-rich shales is well known (McKelvey and Chase, 1966). Both organic-rich shales and phosphorites require a massive source of nutrients abundant in centers of upwelling (Tooms et al., 1969). The absence of Quaternary phosphorites in the Borderland (Kolodny and Kaplan, 1970) suggests a change in some parameters critical to phosphorite formation between the Pliocene and the Quaternary. This change parallels the one we see at the top of the section at Site 467, where a decrease in TOC values suggests a lessening in the intensity of upwelling. More work is needed before the processes causing these changes are fully understood.

The deeper-water sites (469-473) contain little organic matter and do not show the vertical changes in TOC that we see in the Borderland. Apparently these deeper-water sites have been well below the oxygen minimum zone throughout their sedimentary histories.

\section{CONCLUSIONS}

The kerogen fraction of sediments of the deep sea off California $(>2500 \mathrm{~m})$ does not show any evidence for lateral shifts in surface currents, probably because the water is too deep and too oxidizing to permit extensive preservation of this material.

In the California Borderland we interpret the vertical changes in TOC content in terms of a late MiocenePliocene expansion of the oxygen minimum zone. This expansion probably was a response to increased upwelling and surface productivity caused by changes in surface circulation that occurred at the end of the middle Miocene. The result was more extensive accumulation of marine organic matter during the late Miocene and during the Pliocene. In the Quaternary, surface circulation changed again, making conditions less favorable for the accumulation of organic matter at the San Miguel Gap (though not in shallower basins; see Emery, 1960). The changes in TOC were accompanied by changes in phosphorite formation. Phosphorite formed extensively throughout the Borderland in the late Miocene-Pliocene. Presumably more nutrients were available at that time than before or since. Phosphorite formation peaked in the late Miocene and diminished during the Pliocene (Emery, 1960); TOC enrichment at Site 467 was less confined in time, extending through the Pliocene.

Although the sediments of the Borderland are rich in marine organic matter and make excellent potential source rocks for petroleum, they have not yet been heated sufficiently at these DSDP sites to yield liquid hydrocarbons. They contain abundant gas, mostly methane, of probable biogenic origin.

\section{ACKNOWLEDGMENTS}

Chemical analyses were made by M. S. Bisotooni and H. M. Fry at Exxon Production Research Company. D. Gilbert made the kerogen analyses and determined the thermal alteration indices. We thank Ex- 
xon Production Research Company for continued support of this work and for permission to publish these results. J. Kulla and W. A. Young reviewed the manuscript.

\section{REFERENCES}

Demaison, G. J., and Moore, G. T., 1980. Anoxic environments and oil source bed genesis. In I. Breyer (Ed.), Org. Geochem., 2:9-31.

Emery, K. O., 1960. The Sea off Southern California: New York (John Wiley \& Sons, Inc.).

Gilbert, D., Summerhayes, C. P., and Johnson, D. L., 1980. Nature, origin, and source potential of organic Matter in the Japan Trench. In Scientific Party, Init. Repts. DSDP, 56, 57, Pt. 1: Washington (U.S. Govt. Printing Office), 1327-1330.

Ingle, J. C., 1973. Summary comments on Neogene biostratigraphy, physical stratigraphy, and paleo-oceanography in the marginal northeastern Pacific Ocean. In Kulm, L. D., von Huene, R., et al., Init. Repts. DSDP, 18: Washington (U.S. Govt. Printing Office), 949-960.

Kolodny, Y., and Kaplan, I. R., 1970. Uranium isotopes in sea-floor phosphorites. Geochim. Cosmochim. Acta, 34:3-24.

Masran, Th. C., and Pocock, S. A. J., 1979. The classification of plant-derived particulate organic matter in sedimentary rocks. In Staplin, F. L. (Ed.), Kerogen-Visual and Chemical Relationships, a Symposium: Dallas (American Association of Stratigraphic Palynologists), p. 3.

McIver, R. D., 1972. Geochemical significance of gas and gasolinerange hydrocarbons and other organic matter in a Miocene sample from Site 134-Balearic Abyssal Plain. In Ryan, W. B. F., Hsü, K. J., et al., Init. Repts. DSDP, 13: Washington (U.S. Govt. Printing Office), 813-816.

1973a. Hydrocarbon gases from canned core samples, Sites 174A, 176, and 180. In Kulm, L. D., von Huene, R., et al. Init. Repts. DSDP, 18: Washington (U.S. Govt. Printing Office), 10131014.

, 1973b. Hydrocarbons in canned muds from Sites 185, 186, 189, and 191-Leg 19. In Creager, J. S., Scholl, D. W., et al. Init. Repts. DSDP, 19: Washington (U.S. Govt. Printing Office), 875-877.

McKelvey, V., and Chase, L. 1966. Selecting areas favorable for subsea prospecting. Trans. Mar. Tech. Soc., 44-60.

Staplin, F. L., 1969. Sedimentary organic matter, organic metamorphism, and oil and gas occurrence. Bull. Can. Petrol. Geol., 17:47-66.

Tooms, J. S., Summerhayes, C. P., and Cronan, D. S., 1969. Geochemistry of marine phosphate and manganese deposits. In $\mathrm{H}$. Barnes (Ed.), Oceanogr. Mar. Biol., 7:49-60. 